\title{
DETERMINANTS OF ADMINISTRATIVE EFFECTIVENESS IN HIGHER EDUCATION: A STUDY OF OCCUPATIONAL EFFICACY, ADMINISTRATIVE BEHAVIOR AND JOB SATISFACTION OF EDUCATIONAL ADMINISTRATORS WORKING IN INDIAN UNIVERSITIES
}

\author{
Firdous Ahmad Sofal \\ Assistant Professor, Department of Teacher Education, School of Education, \\ Central University of Kashmir, India
}

\begin{abstract}
The present study was conducted to study the occupational efficacy, administrative Behavior and job satisfaction of educational administrators in higher education The descriptive method of research was employed to carry out this piece of research. A sample of 260 Educational Administrators was selected from the existing universities of Jammu and Kashmir State. Occupational Self Efficacy Scale (OSES) by Sanjaypot Pethe, Sushma Chowdari and Uppinar Dhar (1999), Administrative Behavior Scale (ABS) developed by Haseen Taj and Job Satisfaction scale developed by Amar Singh and T.R Sharma were used to collect the data. Significant positive correlation was found between occupational efficacy, administrative Behavior and job satisfaction of educational administrators in higher education. The results also revealed a significant difference between effective and ineffective educational administrators on all dimensions of administrative behavior and job satisfaction.
\end{abstract}

\section{KEYWORDS}

Higher Education, Educational Administrators, Occupational Efficacy, Administrative Behavior, Job Satisfaction.

\section{INTRODUCTION}

Good education is the product of good administration. Administration is not simply a managerial occupation; it demands new dimensions of knowledge, techniques and skills (Chandrasekaran, 1994). In the present world, education is a complex and highly specialized field. Its efficient administration requires technical competence, administrative acumen and understanding of the educational development. Competent and effective administrators are of vital importance to the success of every dynamic organization. Today, educational administrators have multifaceted roles to play. They are expected to uphold the highest standards in professional commitment, DOI : $10.5121 /$ ije.2017.5401 
communication interpersonal skills, classroom personality, emotional maturity and academic integrity. The effective administration of a college or a university requires administrators with good management skills, productive occupational efficacy, effective administrative Behavior, appropriate managerial aptitude, high degree of organizational commitment and high degree of job satisfaction (Ubben and Hughes, 1992).

\section{SIGNIFICANCE OF THE STUDY}

Over the past few decades, higher education institutions all over the world have been confronted with new demands and challenges in terms of restructuring, management and maintaining standards to improve their competitiveness (Chevaillier, 2002; Gamage \& Mininberg, 2003; Harman, 2002; Henkel, 2002; Reponen, 1999). It has been argued that changes in social, technological and cultural systems and needs for socio-economic development, require change in higher education systems (Chevaillier, 2002; Gamage \& Mininberg, 2003). In contemporary times when knowledge has become an essential source of fostering and sustaining socioeconomic development, the role of higher education has expanded (Gamage \& Mininberg, 2003; Kazi, 1977). Universities in particular, are expected to produce, extend and transmit knowledge in a way that provides skilled personnel in all spheres of life and equips students with the necessary skills for successful careers (Broadbent, 1998; Husain, et al., 1988).

Researchers at higher educational level have emphasized improving administrative and management practices, teaching and research structures in universities (Cross, 2000; Fraser \& Cheers, 2000; Harrison \& Brodeth, 1999; Reponen, 1999; Sundberg, 2001). It has been argued that departments are the basic units to be transformed and there is a paucity of research on administering change at this level (Henkel, 2002; Smith, 2002). A host of studies (Bandura, 1982, 1986; Covington, 1984; Dimmock \& Hattie, 1996; Gibson \& Dembo, 1984) have been carried out in the area of educational administration on the variables like occupational self efficacy. They also see: complexity as a challenge (Pajares, 2000); to be engaged (Pajares, 2000); failure as indication that more effort is needed (Bandura, 1986; Collins, 1984; Pajares, 2000); choose specific strategies to enhance learning (Zimmerman and Bandura, 1994); and attribute success to ability (Pajares, 1995). Not only does self-efficacy mediate behavior, but it also affects outcomes. Individuals with higher self-efficacy in a particular organization perform better and are more likely to be interested in a career in that field (Lopez and Lent, 1992; Pajares, 1997). Shoen and Winocur (1988) indicate that there is a positive correlation between self-efficacy and performance. McLeod (1995) examined self-efficacy in teaching and found that this concept affected both teaching and the students' outcomes. Dunkin (1995) investigated how college faculties assessed the teaching effectiveness, self-efficacy of teaching and criteria for selfevaluation among novice and expert teachers. Differences were found in all of these areas.

\section{OBJECTIVES}

- To study the Occupational Efficacy, Administrative Behavior and Job Satisfaction of Educational Administrators working in the Universities of Jammu and Kashmir State in relation to Gender and length of service.

- To undertake a Correlational Analysis of Occupational Efficacy, Administrative Behavior and Job Satisfaction of Educational Administrators. 
International Journal of Education (IJE) Vol.5, No.3/4, December 2017

- To compare Effective and Ineffective Educational Administrators working in the Universities of Jammu and Kashmir State on Administrative Behavior and Job Satisfaction.

\section{HYPOTHESES}

- Occupational Efficacy is significantly related with Administrative Behavior and Job Satisfaction of Educational Administrators.

- Administrative Behavior is significantly related with Job Satisfaction of Educational Administrators.

- Effective and Ineffective educational administrators differ significantly on Administrative Behavior and Job Satisfaction.

\section{DESIGN OF THE STUDY}

\subsection{SAMPLE}

The sample for the present investigation consisted of 260 Educational Administrators selected from the existing Universities of Jammu and Kashmir State.

\subsection{RESEARCH TOOLS}

Occupational Self Efficacy Scale (OSES) developed by Sanjaypot Pethe, Sushma Chowdari and Uppinar Dhar (1999), Administrative Behavior Scale (ABS) by Haseen Taj (2011) and Job Satisfaction Scale (1996) developed by Amar Singh and T.R Sharma were used to collect the required data.

\section{ANALYSIS OF DATA}

The details are given in the tabular form as follows:

Table 1.0:Showing the levels of Occupational Efficacy of Educational Administrators Working in the Universities of Jammu and Kashmir State (N=260)

\begin{tabular}{|c|c|c|l|}
\hline $\begin{array}{c}\text { Scores Obtained } \\
\text { on OSE Scale }\end{array}$ & $\mathbf{N}$ & Percentage & \multicolumn{1}{|c|}{ Status } \\
\hline 83 and Above & 108 & $41.54 \%$ & Above Average \\
\hline $65---82$ & 128 & $49.23 \%$ & Average \\
\hline Below 64 & 24 & $9.23 \%$ & Below Average \\
\hline
\end{tabular}

Table 1.0 shows the levels of occupational efficacy of Educational Administrators in higher education. The data depicts that $41.54 \%$ of the educational administrators in higher education fall in the above average category on occupational efficacy whereas $49.23 \%$ of the educational administrators fall in the average category. The data further reveals that $9.23 \%$ of the educational administrators in higher education fall in the below average category so far as their occupational efficacy is concerned. 
International Journal of Education (IJE) Vol.5, No.3/4, December 2017

Table 1.1: Showing the levels of Occupational Efficacy of Male and Female Educational Administrators Working in the Universities of Jammu and Kashmir State (N=260)

\begin{tabular}{|c|c|c|l|}
\hline \multirow{2}{*}{$\begin{array}{c}\text { Scores Obtained } \\
\text { on OSE Scale }\end{array}$} & \multicolumn{2}{|c|}{ Occupational Efficacy } & \multirow{2}{*}{$\begin{array}{l}\text { Status of } \\
\text { Efficacy }\end{array}$} \\
\cline { 2 - 3 } Male & Female & Above \\
\hline \multirow{2}{*}{63 and Above } & $\begin{array}{c}44.91 \% \\
(\mathrm{~N}=97)\end{array}$ & $\begin{array}{c}25.0 \% \\
(\mathrm{~N}=11)\end{array}$ & Average \\
\hline \multirow{2}{*}{$65---82$} & $50.93 \%$ & $40.91 \%$ & Average \\
& $(\mathrm{N}=110)$ & $(\mathrm{N}=18)$ & \\
\hline \multirow{2}{*}{ Below 64 } & $\begin{array}{c}4.16 \% \\
(\mathrm{~N}=09)\end{array}$ & $\begin{array}{l}34.09 \% \\
(\mathrm{~N}=15)\end{array}$ & $\begin{array}{l}\text { Below } \\
\text { Average }\end{array}$ \\
\hline
\end{tabular}

Table 1.1 shows that $44.91 \%$ male educational administrators in higher education fall in the above average category, whereas $25.0 \%$ female educational administrators fall in this category. In the average category $50.93 \%$ were male and $40.91 \%$ were female educational administrators. It is worthwhile to note that in the below average category, a sizable percentage $(34.09 \%)$ is that of female administrators as compared to male administrators whose percentage is relatively much lower $(4.16 \%)$. The analysis further reveals that since a significant percentage of male educational administrators fall in effective level against female administrators. Therefore, it may be inferred that gender of the educational administrators is an important factor that conditions the occupational efficacy of educational administrators.

Table 1.2: Showing the levels of Occupational Efficacy of Senior and Junior Educational Administrators Working in the Universities of Jammu and Kashmir State $(\mathrm{N}=260)$

\begin{tabular}{|c|c|c|l|}
\hline \multirow{2}{*}{$\begin{array}{c}\text { Scores Obtained } \\
\text { on OSE Scale }\end{array}$} & \multicolumn{2}{|c|}{ Occupational Efficacy } & \multirow{2}{*}{ Status } \\
\cline { 2 - 3 } Senior & Junior & \\
\hline \multirow{2}{*}{83 and Above } & $45.97 \%$ & $32.55 \%$ & Above \\
& $(\mathrm{N}=80)$ & $(\mathrm{N}=28)$ & Average \\
\hline \multirow{2}{*}{$65---82$} & $51.15 \%$ & $45.35 \%$ & Average \\
\hline \multirow{2}{*}{ Below 64 } & $(\mathrm{N}=89)$ & $(\mathrm{N}=39)$ & \\
& $2.88 \%$ & $22.10 \%$ & Below \\
& $(\mathrm{N}=05)$ & $(\mathrm{N}=19)$ & Average \\
\hline
\end{tabular}

A perusal of above table shows that $45.97 \%$ senior educational administrators in higher education fall in the above average category on occupational self efficacy whereas a relatively less percentage of $(32.55 \%)$ junior educational administrators fall in this category. In the average category, $51.15 \%$ were senior and $45.35 \%$ as junior educational administrators.

It is worthwhile to mention that only $2.88 \%$ senior educational administrators fall in the below average category as compared to junior educational administrators whose percentage seems to be much higher $(22.10 \%)$ on occupational efficacy.

The analysis further reveals that since a significant percentage of senior educational administrators fall in effective level as against junior administrators. So, it may be inferred that length of service is an important factor that conditions the occupational efficacy of educational administrators. 
International Journal of Education (IJE) Vol.5, No.3/4, December 2017

Table 1.3: Showing the levels of Administrative Behavior of Educational Administrators Working in the Universities of Jammu and Kashmir State $(\mathrm{N}=260)$

\begin{tabular}{|c|c|c|l|}
\hline $\begin{array}{c}\text { Scores Obtained } \\
\text { on AB Scale }\end{array}$ & N & Percentage & \multicolumn{1}{|c|}{ Status } \\
\hline 278 and Above & 29 & $11.15 \%$ & Very High \\
\hline $248---277$ & 87 & $33.46 \%$ & High \\
\hline $218---247$ & 62 & $23.85 \%$ & Above Average \\
\hline $178---217$ & 45 & $17.30 \%$ & Average \\
\hline $158---177$ & 18 & $6.92 \%$ & Below Average \\
\hline $148---157$ & 15 & $5.77 \%$ & Low \\
\hline 147 and Below & 04 & $1.54 \%$ & Very Low \\
\hline
\end{tabular}

A perusal of table 1.3 shows that $11.15 \%$ educational administrators in higher education possess very high whereas $33.46 \%$ exhibit high administrative Behavior. The data further reveals that $23.85 \%$ of educational administrators in higher education fall in the above average category, $17.30 \%$ educational administrators fall in the average category and $6.92 \%$ educational administrators fall in the below average category of administrative Behavior. The data also reveals that $5.77 \%$ educational administrators possess low administrative Behavior and a very small amount i.e., 1.54\% exhibit very low administrative Behavior.

Table 1.4: Showing the levels of Administrative Behavior of Male and Female Educational Administrators Working in the Universities of Jammu and Kashmir State $(\mathrm{N}=260)$

\begin{tabular}{|c|c|c|c|}
\hline \multirow{2}{*}{$\begin{array}{c}\text { Scores Obtained on AB } \\
\text { Scale }\end{array}$} & \multicolumn{2}{|c|}{ Administrative Behavior } & \multirow{2}{*}{$\begin{array}{l}\text { Status of } \\
\text { Behavior }\end{array}$} \\
\hline & Male & Female & \\
\hline 278 and Above & $\begin{array}{l}12.03 \% \\
(\mathrm{~N}=26)\end{array}$ & $\begin{array}{l}6.81 \% \\
(\mathrm{~N}=03)\end{array}$ & Very High \\
\hline $248---277$ & $\begin{array}{l}37.50 \% \\
(\mathrm{~N}=81)\end{array}$ & $\begin{array}{l}13.63 \% \\
(\mathrm{~N}=06)\end{array}$ & High \\
\hline $218--247$ & $\begin{array}{l}25.0 \% \\
(\mathrm{~N}=54)\end{array}$ & $\begin{array}{l}18.18 \% \\
(\mathrm{~N}=08)\end{array}$ & Above Average \\
\hline $178---217$ & $\begin{array}{l}15.74 \% \\
(\mathrm{~N}=34)\end{array}$ & $\begin{array}{l}25.0 \% \\
(\mathrm{~N}=11)\end{array}$ & Average \\
\hline $158---177$ & $\begin{array}{l}5.09 \% \\
(\mathrm{~N}=11)\end{array}$ & $\begin{array}{l}15.90 \% \\
(\mathrm{~N}=07)\end{array}$ & Below Average \\
\hline $148---157$ & $\begin{array}{l}3.70 \% \\
(\mathrm{~N}=08)\end{array}$ & $\begin{array}{l}15.90 \% \\
(\mathrm{~N}=07)\end{array}$ & Low \\
\hline 147 and Below & $\begin{array}{l}0.92 \% \\
(\mathrm{~N}=02)\end{array}$ & $\begin{array}{l}4.54 \% \\
(\mathrm{~N}=02)\end{array}$ & Very Low \\
\hline
\end{tabular}

A quick look on table 4.4 shows that $12.03 \%$ male educational administrators in higher education were found to possess very high administrative Behavior, whereas only $6.81 \%$ female educational administrators fall in this category. A significant percentage of male educational administrators $(37.5 \%)$ show high administrative Behavior whereas $13.63 \%$ female educational administrators fall in this category. $25.0 \%$ and relatively low percentage of $18.18 \%$ female educational administrators fall in above average category of administrative Behavior. 15.74\% male and a sizeable percentage of $25.0 \%$ female educational administrators exhibit average administrative Behavior. It is worthwhile to mention that in the below average zone of administrative Behavior, a good percentage of $15.90 \%$ are of female educational administrators as compared to male administrators whose percentage is relatively much lower $(5.09 \%)$. It is a gain worth to note here that only $3.70 \%$ male educational administrators possess low administrative Behavior whereas $15.90 \%$ female educational administrators fall in this category. The data further reveals that $0.92 \%$ male educational administrators exhibit very low administrative Behavior, whereas $4.54 \%$ female educational administrators fall in this category. The analysis further reveals that since a significant percentage of male administrators fall in effective level as against the female 
educational administrators. Therefore, it may be inferred that gender is an important factor that conditions the administrative Behavior of the educational administrators.

Table 1.5: Showing the levels of Administrative Behavior of Senior and Junior Educational Administrators Working in the Universities of Jammu and Kashmir State $(\mathrm{N}=260)$

\begin{tabular}{|c|c|c|c|}
\hline \multirow{2}{*}{$\begin{array}{c}\text { Scores Obtained on } \\
\text { AB Scale }\end{array}$} & \multicolumn{2}{|c|}{$\begin{array}{c}\text { Administrative } \\
\text { Behavior }\end{array}$} & \multirow{2}{*}{$\begin{array}{l}\text { Status of } \\
\text { Behavior }\end{array}$} \\
\hline & Senior & Junior & \\
\hline 278 and Above & $\begin{array}{l}14.36 \% \\
(\mathrm{~N}=25)\end{array}$ & $\begin{array}{l}4.65 \% \\
(\mathrm{~N}=04)\end{array}$ & Very High \\
\hline $248---277$ & $\begin{array}{l}35.05 \% \\
(\mathrm{~N}=61)\end{array}$ & $\begin{array}{l}30.23 \% \\
(\mathrm{~N}=26)\end{array}$ & High \\
\hline $218---247$ & $\begin{array}{l}25.28 \% \\
(\mathrm{~N}=44)\end{array}$ & $\begin{array}{l}20.93 \% \\
(\mathrm{~N}=18)\end{array}$ & $\begin{array}{l}\text { Above } \\
\text { Average }\end{array}$ \\
\hline $178--217$ & $\begin{array}{l}16.09 \% \\
(\mathrm{~N}=28)\end{array}$ & $\begin{array}{l}19.76 \% \\
(\mathrm{~N}=17)\end{array}$ & Average \\
\hline $158--177$ & $\begin{array}{l}4.59 \% \\
(\mathrm{~N}=08)\end{array}$ & $\begin{array}{l}11.62 \% \\
(\mathrm{~N}=10)\end{array}$ & $\begin{array}{l}\text { Below } \\
\text { Average }\end{array}$ \\
\hline $148--157$ & $\begin{array}{l}4.02 \% \\
(\mathrm{~N}=07)\end{array}$ & $\begin{array}{l}9.30 \% \\
(\mathrm{~N}=08)\end{array}$ & Low \\
\hline 147 and Below & $\begin{array}{l}0.57 \% \\
(\mathrm{~N}=01)\end{array}$ & $\begin{array}{l}3.48 \% \\
(\mathrm{~N}=03)\end{array}$ & Very Low \\
\hline
\end{tabular}

Table 1.5 shows that $14.36 \%$ senior educational administrators possess very high administrative Behavior whereas a very small percentage of junior educational administrators fall in this category $(4.65 \% 0.35 .05 \%$ senior and almost a similar percentage of $(30.23 \%)$ junior educational administrators possess high administrative Behavior. The data further reveals that $25.28 \%$ senior educational administrators fall in the above average category on administrative Behavior whereas $20.93 \%$ junior educational administrators fall in this category. $16.09 \%$ senior and relatively high percentage (19.76\%) junior educational administrators are reported to be in average category of administrative Behavior. It is worthwhile to note that a sizeable amount of junior educational administrators were found to have below average administrative Behavior (11.62\%), whereas only $4.59 \%$ senior educational administrators fall in this category. The results also reveal that 9.30\% junior educational administrators show low administrative Behavior, whereas $4.02 \%$ senior educational administrators fall in this category. $3.48 \%$ junior and $0.57 \%$ senior educational administrators exhibit low administrative Behavior. The analysis further reveals that since a significant percentage of senior educational administrators possess high administrative Behavior as against the junior educational administrators. Therefore, it may be generalized that length of service is an important factor that conditions the administrative Behavior of educational administrators.

Table 1.6: Showing the Relationship between Occupational Efficacy and Administrative Behavior of Educational Administrators $(\mathrm{N}=260)$

\begin{tabular}{|l|c|c|c|}
\hline Variable & $\begin{array}{l}\text { Occupation } \\
\text { al Efficacy }\end{array}$ & $\begin{array}{l}\text { Administrativ } \\
\text { e Behavior }\end{array}$ & $\begin{array}{l}\text { Job } \\
\text { Satisfactio } \\
\text { n }\end{array}$ \\
\hline $\begin{array}{l}\text { Occupational } \\
\text { Efficacy }\end{array}$ & $*$ & 0.68 & 0.69 \\
\hline $\begin{array}{l}\text { Administrative } \\
\text { Behavior }\end{array}$ & & $*$ & 0.58 \\
\hline Job Satisfaction & & & $*$ \\
\hline
\end{tabular}


International Journal of Education (IJE) Vol.5, No.3/4, December 2017

A perusal of table 1.6 reveals that there is a significant positive correlation between Occupational Efficacy and Administrative Behavior. The co-efficient of correlation came out to be $\mathrm{r}=0.68$ (p>.01) which is significant at .01 level of significance. The table reveals that Occupational Efficacy is positively related with Administrative Behavior of Educational Administrators. This suggests that more the occupational efficacy, higher shall be the rating of administrative Behavior.

In the light of empirical evidence discussed above, the hypothesis number one which reads "Occupational Efficacy is significantly related with Administrative Behavior of Educational Administrators" stands accepted.

The table further reveals that there is a significant positive correlation between Occupational Efficacy and Job Satisfaction. The co-efficient of correlation between these two variables came out to be $r=0.69$ ( $p>.01)$ which is significant at 0.01 level of significance. The table reveals that Occupational Efficacy is positively related with Organizational Commitment of Educational Administrators. This indicates that more the occupational efficacy, higher shall be the rating of organizational commitment.

In the light of empirical evidence discussed above, the hypothesis number two which reads "Occupational Efficacy is significantly related with Job Satisfaction of Educational Administrators" stands accepted.

Table 1.6 also depicts that there is a significant positive correlation between Administrative Behavior and Job Satisfaction. The co-efficient of correlation between these two variables came out to be $r=0.58$ ( $p>.01)$ which is significant at .01 level of significance. The table further reveals that Administrative Behavior is positively related with Job Satisfaction of Educational Administrators. This suggests that more the Administrative Behavior, higher shall be the rating of Job Satisfaction.

In the light of empirical evidence discussed above, the hypothesis number three which reads "Administrative Behavior is significantly related with Job Satisfaction of Educational Administrators" stands accepted.

\section{Comparison of Effective and Ineffective Educational Administrators on Administrative Behavior and Job Satisfaction}

In order to make a comparative evaluation of effective and ineffective educational administrators working in the universities of Jammu and Kashmir State as a first step, effective and ineffective educational administrators were identified on the basis of criterion of occupational efficacy measured with the help of Occupational Self Efficacy Scale. The high and low groups were drawn by employing extreme group technique of $27 \%$ above and below. As such the above $27 \%$ $(\mathrm{N}=70)$ educational administrators possessing high score were identified as effective educational administrators and $27 \%(\mathrm{~N}=70)$ educational administrators possessing low score were identified as ineffective educational administrators. This was followed by a comparative evaluation of effective and ineffective educational administrators on administrative Behavior and job satisfaction. 
International Journal of Education (IJE) Vol.5, No.3/4, December 2017

Table 1.7 Showing the Significance of Difference between the Mean Scores of Effective and Ineffective Educational Administrators on Various Dimension of Administrative Behavior Scale ( $N=70$ Each)

\begin{tabular}{|c|c|c|c|c|c|c|}
\hline Dimensions & Group & Mean & S.D & SEM & t-value & Remarks \\
\hline \multirow{2}{*}{ Planning } & $\begin{array}{l}\text { Effective Educational } \\
\text { Administrators }\end{array}$ & 74.89 & 7.94 & 0.94 & \multirow{2}{*}{6.52} & \multirow{2}{*}{$\begin{array}{c}0.01 \\
\text { Level }\end{array}$} \\
\hline & $\begin{array}{l}\text { Ineffective Educational } \\
\text { Administrators }\end{array}$ & 66.74 & 6.88 & 0.82 & & \\
\hline \multirow{2}{*}{ Organization } & $\begin{array}{l}\text { Effective Educational } \\
\text { Administrators }\end{array}$ & 91.32 & 11.76 & 1.40 & \multirow{2}{*}{5.55} & \multirow{2}{*}{$\begin{array}{c}0.01 \\
\text { Level }\end{array}$} \\
\hline & $\begin{array}{l}\text { Ineffective Educational } \\
\text { Administrators }\end{array}$ & 81.15 & 9.88 & 1.18 & & \\
\hline \multirow{2}{*}{$\underset{n}{\text { Communicatio }}$} & $\begin{array}{l}\text { Effective Educational } \\
\text { Administrators }\end{array}$ & 99.76 & 10.93 & 1.30 & \multirow{2}{*}{6.40} & \multirow{2}{*}{$\begin{array}{c}0.01 \\
\text { Level }\end{array}$} \\
\hline & $\begin{array}{l}\text { Ineffective Educational } \\
\text { Administrators }\end{array}$ & 88.62 & 9.76 & 1.16 & & \\
\hline \multirow{2}{*}{$\begin{array}{l}\text { Decision } \\
\text { Making }\end{array}$} & $\begin{array}{l}\text { Effective Educational } \\
\text { Administrators }\end{array}$ & 45.12 & 6.89 & 0.82 & \multirow{2}{*}{5.91} & \multirow{2}{*}{$\begin{array}{c}0.01 \\
\text { Level }\end{array}$} \\
\hline & $\begin{array}{l}\text { Ineffective Educational } \\
\text { Administrators }\end{array}$ & 38.79 & 5.96 & 0.71 & & \\
\hline \multirow{2}{*}{$\begin{array}{c}\text { Overall } \\
\text { Dimensions }\end{array}$} & $\begin{array}{l}\text { Effective Educational } \\
\text { Administrators }\end{array}$ & $\begin{array}{c}311.0 \\
9\end{array}$ & 21.76 & 2.60 & \multirow{2}{*}{10.78} & \multirow{2}{*}{$\begin{array}{l}0.01 \\
\text { Level }\end{array}$} \\
\hline & $\begin{array}{l}\text { Ineffective Educational } \\
\text { Administrators }\end{array}$ & $\begin{array}{c}275.3 \\
0\end{array}$ & 17.30 & 2.06 & & \\
\hline
\end{tabular}

A perusal of above table shows the significance of difference between the mean scores of Effective and Ineffective Educational Administrators on 'Planning'; 'Organization'; 'Communication'; 'Decision-Making' and on overall dimensions of administrative Behavior. The results reveal that effective and ineffective educational administrators differ significantly on all the dimensions of administrative Behavior. The effective educational administrators were found to be more competent in planning and effective in organization. They were found to possess effective communication skills and seem to be well versed in decision making processes than their counterparts. From these results, it can be inferred that effective educational administrators possess better administrative Behavior than their counterparts. In the light of above empirical evidences, the hypothesis number fourth which reads, "Effective and Ineffective Educational Administrators working in the Universities of Jammu and Kashmir State differ significantly on Administrative Behavior" stands accepted.

Table 1.7 Showing the Significance of Difference between the Mean Scores of Effective and Ineffective Educational Administrators on Various Dimensions of Job Satisfaction Scale (N=70 Each)

\begin{tabular}{|c|c|c|c|c|c|c|}
\hline Dimensions & Group & Mean & S.D & SEM & t-value & Remarks \\
\hline \multirow{2}{*}{$\begin{array}{l}\text { Job Concrete } \\
\text { Factor }\end{array}$} & $\begin{array}{l}\text { Effective Educational } \\
\text { Administrators }\end{array}$ & 17.21 & 5.12 & 0.61 & \multirow{2}{*}{3.71} & \multirow{2}{*}{ 0.01 Level } \\
\hline & $\begin{array}{l}\text { Ineffective Educational } \\
\text { Administrators }\end{array}$ & 14.13 & 4.72 & 0.56 & & \\
\hline \multirow{2}{*}{$\begin{array}{l}\text { Job Abstract } \\
\text { Factor }\end{array}$} & $\begin{array}{l}\text { Effective Educational } \\
\text { Administrators }\end{array}$ & 18.57 & 4.62 & 0.55 & \multirow{2}{*}{4.83} & \multirow{2}{*}{ 0.01 Level } \\
\hline & $\begin{array}{l}\text { Ineffective Educational } \\
\text { Administrators }\end{array}$ & 15.09 & 3.96 & 0.47 & & \\
\hline \multirow{2}{*}{$\begin{array}{l}\text { Psycho-Social } \\
\text { Factor }\end{array}$} & $\begin{array}{l}\text { Effective Educational } \\
\text { Administrators }\end{array}$ & 20.60 & 6.02 & 0.72 & \multirow{2}{*}{2.36} & \multirow{2}{*}{ 0.05 Level } \\
\hline & $\begin{array}{l}\text { Ineffective Educational } \\
\text { Administrators }\end{array}$ & 18.31 & 5.63 & 0.67 & & \\
\hline
\end{tabular}


International Journal of Education (IJE) Vol.5, No.3/4, December 2017

\begin{tabular}{|c|c|c|c|c|c|c|}
\hline \multirow{2}{*}{$\begin{array}{l}\text { Economic } \\
\text { Factor }\end{array}$} & $\begin{array}{l}\text { Effective Educational } \\
\text { Administrators }\end{array}$ & 11.43 & 2.74 & 0.32 & \multirow{2}{*}{2.16} & \multirow{2}{*}{ 0.05 Level } \\
\hline & $\begin{array}{l}\text { Ineffective Educational } \\
\text { Administrators }\end{array}$ & 10.61 & 2.03 & 0.24 & & \\
\hline \multirow{2}{*}{$\begin{array}{l}\text { Community/ } \\
\text { National } \\
\text { Growth } \\
\text { Factor }\end{array}$} & $\begin{array}{l}\text { Effective Educational } \\
\text { Administrators }\end{array}$ & 11.76 & 2.67 & 0.31 & \multirow{2}{*}{3.35} & \multirow{2}{*}{ 0.01 Level } \\
\hline & $\begin{array}{l}\text { Ineffective Educational } \\
\text { Administrators }\end{array}$ & 10.52 & 1.84 & 0.22 & & \\
\hline $\begin{array}{l}\text { Overall } \\
\text { Dimensions }\end{array}$ & $\begin{array}{l}\text { Effective Educational } \\
\text { Administrators }\end{array}$ & 80.69 & 13.41 & 1.60 & 3.77 & 0.01 Level \\
\hline
\end{tabular}

The results reported in tables 1.7 shows the significance of difference between the mean scores of effective and ineffective educational administrators on Job Satisfaction. The results revealed that both effective and ineffective educational administrators differ significantly on all dimensions of job satisfaction scale. The mean difference favours the effective educational administrators which suggest that they show more satisfaction and contentment with their job than the ineffective educational administrators. They are more satisfied and contended with their job than their counter parts. In the light of above empirical evidences, the hypothesis number fifth which reads, "Effective and Ineffective Educational Administrators working in the Universities of Jammu and Kashmir State differ significantly on Job Satisfaction" stands accepted.

\section{DISCUSSION OF THE RESULTS}

The discussion of the results based on the analysis and interpretation of the data is presented in the following pages. The results are discussed as under:

\section{Occupational efficacy of educational administrators}

On the basis of descriptive analysis, it has been found that $41.54 \%, 49.23 \%$ and $9.23 \%$ educational administrators fall in the above average, average and below average categories respectively. These results suggest that the educational administrators who fall in above average category display confidence, command, adaptability, positive attitude, individuality and personal effectiveness in their job profile. Educational administrators who fall in average category on occupational efficacy revaluate strategies when they fail in any task. It has been further found that educational administrators who fall in below average category of occupational efficacy fail to work effectively and find it difficult to complete the assignment with full dedication and accuracy. The result further reveals that a significant percentage of $44.91 \%$ male educational administrators fall in above average category as compared to female educational administrators whose percentage is relatively much lower $(25.0 \%)$. It has also been found that majority of the male educational administrators i.e. $50.93 \%$ fall in average category, whereas comparatively less percentage of female educational administrators fall in this category $(40.91 \%)$. It is worthwhile to mention that a very small amount of $4.16 \%$ of male educational administrators fall in below average category whereas a sizeable amount of $34.09 \%$ female educational administrators fall in this category. This implies that male educational administrators were found to be more effective than female educational administrators. This finding is in line with the findings of Love, Antoinette (2008), who revealed that male principals scored higher on effective leadership Behavior than the female principals. However, this finding is in contrast with the finding of 
Omoike, D. \& Idogho, P. A. (2006), who reported that there is no significant difference in administrative effectiveness between male and female principals.

45.97\% senior educational administrators in higher education fall in the above average category whereas a relatively low percentage of junior educational administrators fall in this category $(32.55 \%)$. The results further reveal that majority of the senior educational administrators i.e., $51.15 \%$ were found to have average occupational efficacy whereas a relatively small amount of junior educational administrators $(45.35 \%)$ fall in this category. It is worthwhile to mention that only $2.88 \%$ of senior educational administrators fall in the below average category as compared to junior educational administrators whose percentage was found to be relatively much higher $(22.10 \%)$ on occupational efficacy. This confirms that senior educational administrators were found to be more effective than junior educational administrators. This finding is in line with the findings of Jeanmarie \& Tonyia, M. (2008), who found that Principals with more experience in education viewed the performance appraisal process as beneficial to performance outcomes. Mensik (2006) also reported that effective principals, with more than five years of administrative services, were visionary who set a positive climate by communicating well with others. They build relationships and work with their constituents and have a strong moral and ethical foundation.

\section{Administrative Behavior of Educational Administrators}

It has been found that majority of the educational administrators $(68.46 \%)$ fall in the three effective levels (very high, high and above average) of administrative Behavior. This implies that majority of the educational administrators were found to be more competent in planning and effective in organization. The data also revealed that male educational administrators score higher on administrative Behavior than their counterparts. This confirms that male educational administrators were found to have relatively more effective administrative qualities than female educational administrators. The data further revealed that male educational administrators encourage participative decision making and appreciate good work culture from their colleagues and subordinates. This finding is in line with the findings of Love, Antoinette (2008), who revealed that male principals scored higher on effective leadership Behavior than the female principals.

On the basis of descriptive analysis and interpretation, it has also been found that a significant percentage of senior educational administrators (74.69\%) in higher education fall in the effective levels (very high, high and above average) of administrative Behavior. Whereas, a relatively less percentage of junior educational administrators (55.81\%) fall in these effective levels. 16.09\% senior and almost similar percentage $(19.76 \%)$ junior educational administrators fall in the average category. It is worth to note that $4.59 \%, 4.02 \%$ and $0.57 \%$ senior educational administrators in higher education fall in the below average, low and very low categories of administrative Behavior respectively whereas, $11.62 \%, 9.30$ and $3.84 \%$ junior educational administrators fall in these levels respectively. This clearly confirms that senior educational administrators were found to have effective administrative Behavior than their counterparts. However, this finding is in contrast with the finding of Nanda, (1992), who reported that length of experience in no way contributes the leadership Behavior amongst the heads of primary schools. 


\section{Correlational Analysis of Occupational Efficacy, Administrative Behavior and Job Satisfaction of Educational Administrators}

While investigating the relationship between occupational efficacy and administrative Behavior of educational administrators, the data reveals that there is a significant positive relationship between occupational efficacy and administrative Behavior of educational administrators. The results reveal that the educational administrators who exhibit better confidence level to work independently, ensure proper organization of academic and administrative matters of their institution and analyze thoroughly the situation before taking any decision. This suggests that more the occupational efficacy, higher shall be the rating of administrative Behavior. The finding is in agreement with the findings of Runhaar et al. (2010), who found that there is a positive relationship between occupational self efficacy and transformational leadership Behavior. Griffin (2008), found a positive relationship between self efficacy and perceived transformational leadership Behavior. Kumar (1986), found that self-concept combined with confidence was found to be a significant predictor of administrative effectiveness. Das, (1983), reported that there is significant positive relationship between principals' administrative Behavior and teachers' attitude towards work and work setting of the institution.

On the basis of analysis and interpretation, it has been found that there is positive relationship between Occupational Efficacy and Job Satisfaction of Educational Administrators. This indicates that the Educational administrator's who exhibit better confidence level to work independently are satisfied with the economic advantages of their jobs like salary, allowance, increment and rate their job excellent with regard to post retirement benefits like pension, gratuity etc. The table depicts that the occupational efficacy of educational administrators is positively correlated with their job satisfaction. This suggests that higher the score of occupational efficacy more will be the rating of job satisfaction. This finding is in line with the findings of Adebomi, Olufunke \& Oluyemisi (2012), who found that there is positive significant relationship between self-efficacy and job satisfaction of special education teacher. Kwong, Walker \& Allan (2010), found a positive correlation between occupational efficacy and job satisfaction of vice principals. De Nobile \& McCormick (2007), found that there is strong to moderate correlation between job satisfaction and occupational stress. The finding is also in correspondence with the findings of Kukreti (1994), who found a positive correlation between teacher competence and job satisfaction. Johnson (1990), found a positive relationship between school effectiveness, principal effectiveness and job satisfaction of the principals, However, the finding is in contrast with the findings of Gamber (2005) who found that there is no relationship between self efficacy and job satisfaction.

It has been further found that there is a positive relationship between Administrative Behavior and Job Satisfaction $(\mathrm{r}=0.58 ; \mathrm{p}>.01)$. The results revealed that the educational administrators who exhibit better abilities in planning, organizing, directing, controlling, financing and evaluating are satisfied with the economic advantages of their jobs like salary, allowance, increment and rate their job excellent with regard to post retirement benefits like pension, gratuity etc. This suggests that more the score of administrative Behavior higher shall be the rating of job satisfaction. The finding is in agreement with the findings of Muindi (2011), who indicated that there is a significant strong positive correlation between job satisfaction and participation in decisionmaking. Frances (2009), revealed that there exists a significant relationship between transformational leadership Behavior and teachers' job satisfaction. Sharma (1991), found a positive relationship between the principal's administrative Behavior and job satisfaction. 
International Journal of Education (IJE) Vol.5, No.3/4, December 2017

\section{Comparison of Effective and Ineffective Educational Administrators on Administrative Behavior}

Effective and ineffective educational administrators differ significantly on all the dimensions of administrative Behavior. Effective educational administrators exhibited better administrative Behavior than ineffective educational administrators. They have excellent disposal Behavior. They develop plans, identify priorities and define the objectives. In comparison, the ineffective educational administrators show poor administrative Behavior. They are rigid and authoritative in taking any decision. This finding is in line with the findings of Mensik (2006), who found effective principals as visionary and optimistic. Building relationships and good work culture, strong moral and ethical foundations are also reported by the same investigators. Kulsum (1999), concluded that the principals with high initiating structure are more effective. The finding is also in agreement with the findings of Sudha (1997), who found that effective leaders are administratively successful and managerly flexible.

\section{CONCLUSiOnS}

Following conclusions were drawn from the present study:

\section{A. Occupational Efficacy of Educational Administrators:}

i. From the results of the descriptive analysis, it was found that $41.54 \%, 49.23 \%, 9.23 \%$ educational administrators working in the universities of Jammu and Kashmir State fall in the above average, average and below average category, on occupational efficacy respectively. It was further found that the educational administrators within average category display loyalty, perseverance, confidence, enthusiasm and dedication in their job profile. Educational administrators who fall in average category on occupational efficacy are in a position to revaluate strategies when they fail in any task. It has been further found that educational administrators who fall in below average category of occupational efficacy lack the desired administrative skills. They fail to work effectively and find it difficult to complete the assignment with full dedication and accuracy.

ii. It was found that $45.97 \%$ senior and $32.55 \%$ junior educational administrators in higher education fall in above average category of occupational efficacy. Similarly, a significant percentage of $51.15 \%$ senior and comparatively low percentage of junior educational administrators (45.35\%) fall in average category. It was further found that a very small chunk of $2.88 \%$ senior and comparatively high percentage $(22.10 \%)$ junior educational administrators fall in the below average category of occupational efficacy.

\section{B. Administrative Behavior of Educational Administrators}

I. It was found that a significant amount of $68.45 \%$ educational administrators in higher education possess high administrative Behavior and $17.30 \%$ exhibit average administrative Behavior. A sizeable percentage of $14.21 \%$ educational administrators show low administrative Behavior. It was further found that the educational administrators who exhibit high administrative Behavior appreciate the good work culture and try out innovative strategies in solving the group 
International Journal of Education (IJE) Vol.5, No.3/4, December 2017

problems. They encourage others to share their views, choose appropriate communication channels and keep others informed of key and relevant issues.

II. $74.69 \%$ senior and $55.81 \%$ junior educational administrators in higher education possess high administrative Behavior. It was further found that $16.09 \%$ senior and $(19.76 \%)$ junior educational administrators exhibit average administrative Behavior. 9.18\% senior educational administrators show low administrative Behavior, where as a relatively high percentage of $24.4 \%$ junior educational administrators fall in this category.

\section{Comparison of Effective and Ineffective Educational Administrators on Administrative Behavior}

It has been found that there is a significant difference between effective and ineffective educational administrators on 'planning'; 'organization'; 'communication'; decision making and on 'overall dimensions'. The mean difference favoured effective educational administrators which implies that they display better planning abilities, ensure fair administrative procedures, exhibit good communication skills and possess effective decision making potential than their counterparts.

\section{EDUCATIONAL IMPLICATIONS}

Today's world is characterized by accelerating change, exploding knowledge, growing diversity, galloping technology and increasing uncertainty. Presently, administrators are facing rapid changes and complexity of problems in management. The role of educational administrators is changing and demands of the profession are increasing day by day. From the results of the study, it was reported that majority of the educational administrators have been found to exhibit average occupational efficacy. Therefore, suitability should be judged before promoting the administrators to the higher posts. On the other hand junior educational administrators have been found to have comparatively low occupational efficacy. Therefore, short term/long term training in field of management, planning and finance is necessary for the professional growth of junior and female educational administrators.

A significant difference was observed between effective and ineffective educational administrators on all dimensions of administrative Behavior scale. Effective administrators have been found to exhibit better administrative qualities than ineffective ones. Thus, MHRD,UGC, NUEPA etc should organize special training courses, so that the leadership qualities of the educational administrators can be brought to the effective level. A hand book may be prepared for administrators that may guide them in administering their institutions effectively and to become effective institutional leaders.

\section{REFERENCES}

[1] Adebomi, O., Olufunke, I. H., \& Oluyemisi, S. B., (2012). Job satisfaction and self-efficacy as correlates of job commitment of special education teachers in Oyo State. Journal of Education and Practice, Vol. 3, No. 9, Pp. 95-104.

[2] Bandura, A. (1982). Self-efficacy mechanism in human agency. American Psychologist, Vol. 37, No. 2, Pp. 122-147. 
[3] Bandura, A. (1986). Social foundations of thought and action: a social cognitive theory. Prentice-Hall, Englewood Cliffs, NJ.

[4] Broadbent, C. (1998). Transforming the university: tensions and opportunities for academics. Paper presented at the annual conference of the Australian Association of Educational Research (AARE) held in Adelaide, SA, 29 Nov - 3 Dec, 1998.

[5] Chandrasekaran, P. (1994). Educational planning and management. New Delhi: Sterling Publishers Private Limited, Pp.120-124.

[6] Chevaillier, T. (2002). Higher education and its clients: institutional responses to changes in demand and in environment. Higher Education, Vol. 33, No. 6, Pp. 303-308.

[7] Collins, J. L. (1984). Self-efficacy and ability in achievement behavior. Unpublished Ph. D Thesis, Stanford University.

[8] Covington, M. V. (1984). The self-worth theory of achievement motivation: Findings and implications. The Elementary School Journal, Vol. 85, No. 1, Pp. 1-20.

[9] Cross, K. P. (2000). The educational role of researchers. New Directions for Higher Education, Vol. 110, No. 8, Pp. 63-74.

[10] Das, M. (1983). A study of the administrative Behavior of secondary school principals in relation to selected school variables. Unpublished Ph. D. Thesis (Education), MSU University.

[11] De Nobile, J., \& McCormick, John (2005). Job satisfaction and occupational stress in Catholic primary school. Annual Conference of Australian Association for Research in Education, Sydney, 27th November-1st December 2005.

[12] Dimmock, C., \& Hattie, J. (1996). School principals' self-efficacy and its measurement in a context of restructuring. School Effectiveness and School Improvement, Vol. 7, No. 1, Pp. 62-75.

[13] Dunkin, M. J. (1995). Concepts of teaching and teaching excellence in higher education. Higher Education Research and Development, Vol. 14, No. 4, Pp. 21-33.

[14] Frances, D. Turpin (2009). A study examining the effects of transformational leadership Behaviors on the factors of teaching efficacy, job satisfaction and organizational commitment as perceived by special education teachers. Unpublished Ph. D. Dissertation, Faculty of the Virginia Polytechnic Institute, Virginia.

[15] Fraser, S., \& Cheers, M. (2000). What does tertiary teaching need: visionaries or pragmatics? In Herrmann, A., \& Kulski, M. M (Editions). Flexible Futures in Tertiary Teaching. Proceedings of the 9th Annual Teaching Learning Forum, Curtin University of Technology.

[16] Gamage, D. T., \& Mininberg, E. (2003). The Australian and American higher education: key issues of the first decade of the 21st century. Higher Education, Vol. 45, No. 4, Pp. 183-202.

[17] Gamber, J. S. (2005). The relationship of self efficacy and job culture to Job Satisfaction among certified athletic trainers. Dissertation Abstracts International, Vol. 66, No.12, p. 4337 New Delhi: NCERT.

[18] Gibson, S., \& Dembo, M. (1984). Teacher efficacy: A construct validation. Journal of Educational Psychology, Vol. 76, No. 4, Pp. 569-582.

[19] Griffin, G. R. (2008). The relationship of self efficacy, perception of supervisors' leadership style and blue collar engagement style. Cited from Ph. D Thesis of Vinode Kumar Kain, Jamia Millia Islamia, New Delhi.

[20] Harman, G. (2002). Academic leaders or corporate managers: deans and heads in Australian higher education, 1977 to 1997. Higher Education Management and Policy, Vol. 14, No. 2, Pp. 53-70.

[21] Harrison, B. T., \& Brodeth, E. (1999). Real work through real collegiality: faculty seniors' views on the drive to improve learning and research. Journal of Higher Education Policy and Management, Vol. 21, No. 2, Pp. 203-214.

[22] Henkel, M. (2002). Academic identity in transformation? the case of the United Kingdom. Higher Education Management and Policy, Vol. 14, No. 3, pp. 137-147.

[23] Husain, T., Sanyal, B. C., Abbasi, M. H., \& Khan, S. R. (1977). Higher education and employment opportunities in Pakistan. Paris: IIEP Press.

[24] Jeanmarie, \& Toniya, M. (2008). The relationship between principal's perceptions of performance appraisal and levels of job satisfaction. Dissertation Abstracts International, Vol. 66, p. 47-A New Delhi: NCERT. 
International Journal of Education (IJE) Vol.5, No.3/4, December 2017

[25] Johnson, J. (1990). School effectiveness, principals' effectiveness and job satisfaction: a comparison of three school levels. Educational Administration Quarterly. Vol. 3, No. 1, Pp. 163.

[26] Kazi, M. A. (1977). The role of university research in Pakistan's socio-economic development. Sind Quarterly, Vol. 5, No. 2, Pp. 14-32.

[27] Kukreti, B. R. (1994). Job motivation and teacher competency: a co-relational study. Experiments in Education, Vol. 22, No.1, Pp.10-14.

[28] Kumar, D. (2009). A study on leadership Behavior of heads of secondary school and academic achievements of students in mathematics. International Research Journal, Vol. 01, No.2, p.127.

[29] Kwong. Y, Paulo, Walker. K., \& Allan. (2010). Secondary school vice principal: commitment, challenge, efficacy, synchrony. British Educational Research Journal. Vol. 36, No. 4, Pp.531-548.

[30] Lopez, F. G., \& Lent, R. W. (1992). Sources of mathematics self-efficacy in high school students. The Career Development Quarterly, Vol. 41, Pp. 3-12.

[31] Love, Antoinelle (2007). Teacher's perception of the leadership effectiveness of female and male principals. Dissertation Abstracts International, Vol. 68, p. 820-A.

[32] Malik, N. (2004). A study on job satisfaction factors of faculty members at the university of Balochistan. Journal of Research in Education, Vol. 21, No. 2, Pp. 49-57.

[33] McLeod, S. H. (1995). Pygmalion or golem? teacher affect and efficacy. College Composition and Communication, Vol. 46, No. 4, Pp. 369-386.

[34] Meijer, C., \& Foster, S. (1988). The effect of teacher self efficacy on referral chance. Journal of Special Education, Vol. 22, Pp. 378-385.

[35] Mensik, J. (2006). The Framework of an effective principal: a community's perspective. Dissertation Abstracts International, Vol. 68, No.12, p. 4935-A

[36] Milner, H. R. (2002). A case study of an experienced teacher's self efficacy and persistence through crisis situations: Theoretical and practical considerations. The High School Journal, Vol. 86, Pp. 2835.

[37] Muindi, F. K. (2011). The relationship between participation in decision making and job satisfaction among academic staff in the school of business, University of Nairobi. Journal of Human Resources Management Research, Vol. 12, No. 2, Pp. 1-34.

[38] Nanda, A. R. (1992). A study of the leadership Behavior of primary headmasters of Cuttack schools. Citied in M.B Buch (Editor) Fifth Survey of Research in Education. New Delhi: NCERT, p.1837.

[39] Omoike, D., \& Idogho, P. A. (2008). Gender disparity in administrative effectiveness of heads of academic departments in Nigerian Universities. Journal of Social Science, Vol.16, No.3, Pp. 205-208.

[40] Pajares, F. (1995). Self-efficacy in academic settings. Paper presented at the American Educational Research Association, San Francisco, CA.

[41] Pajares, F. (1997). Current directions in self-effiacacy research. In M. Maehr \& P. R. Pintrich (Eds.), Advances in Motivation and Achievement, Vol. 10, Pp. 1-49.

[42] Pajares, F. (2000). Schooling in America: Myths, mixed messages and good intentions. Emory University, Cannon Chapel.

[43] Reponen, T. (1999). Is leadership possible at loosely coupled organizations such as universities? Higher Education Policy, Vol. 12, No. 4, Pp. 237-244.

[44] Riffat-Un-Nisa, A., Zaidi, N. R., Anjum Naz, Ghazala Noureen (2011). Task structure as moderator of college principals' leadership behavior and their subordinates' outcomes. International Education Studies, Vol. 4, No. 1, Pp. 134-143.

[45] Runhaar, Piety \& Sanders (2010). Stimulating teachers' reflection and feedback asking- an interplay of self efficacy. Journal of Research Studies. Vol. 26, No. 5, p.187.

[46] Shoen, L. G., \& Winocur, S. (1988). An investigation of the self-efficacy of male and female academics. Journal of Vocational Behavior, Vol. 32, No. 6, Pp. 307-320.

[47] Sharma, M.S.R. (1991). A Study of the administrative Behavior of principals as perceived by teachers in relation to job satisfaction of teachers in junior colleges. Citied in M. B Buch's (Editor) Fifth Survey of Research in Education, New Delhi: NCERT.

[48] Smith, R. (2002). The role of the university head of department. Educational Management and Administration, Vol. 30, No. 3, Pp. 293-312. 
[49] Sundberg, M. D. (2001). Guest editorial: on being a department chairperson. The American Biology Teacher, Vol. 63, No. 5, Pp. 306-307.

[50] Timothy M. Gaspar (1990). Job satisfaction of chairpersons of nursing departments in academe. Unpublished Ph. D Theses, College of Nursing, University of Uttah.

[51] Ubben, G. C., \& Hughes, L. W. (1992). The principal creative leadership for effective schools. Allyn and Bacon, Boston. p. 2,8,14.

[52] Zimmerman, B. J., \& Bandura, A. (1994). Impact of self regulatory influences on writing course attainment. American Educational Research Journal, Vol. 31, Pp.845-862.

\section{AUTHOR}

Dr. Firdous Ahmad Sofal born at Mohalla Shirpora, Anantnag, Kashmir obtained his Graduation from the University of Kashmir, Srinagar. Pursued for Master's Programme in subject Education and obtained 1st division from the same university. Besides, Dr. Firdous also pursued B.Ed Programme from the University of Kashmir, Srinagar. He has done his M.Phil and Ph.D in the area of Educational Administration and Management. Dr. Firdous Ahmad Sofal qualified UGC NET and also qualified UGC-SET conducted by the University of Kashmir in the year 2013. Dr. Sofal started his career as Assistant Professor in the School of Education, BGSB University,

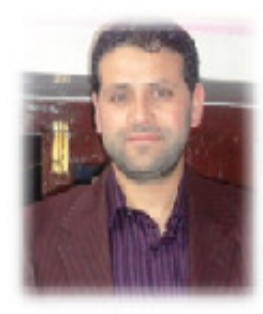
Rajouri where he has served the Department as Head of the Department. Dr. Sofal has also been selected as Assistant Professor by the Jammu and Kashmir Public Service Commission in the year 2017 at S. No. 01. Dr. Sofal possess 08 years of teaching experience at higher education level and presently he is working as Assistant Professor in the School of Education (Teacher Education), Central University of Kashmir, Srinagar. Dr. Sofal has authored 07 text books so far and has to his credit nearly 15 research papers published in various journals of the international/national repute. Dr. Sofal also participated in various seminars and conferences held at Regional, National and International levels. His areas of specialization are Educational administration and Management, Development of Education System in India, Methodology of Educational Research and Psychological Foundations of Education. 